\title{
Innate immune response of the dental pulp in healthy and carious human teeth
}

\author{
Ana Sotirovska Ivkovska ${ }^{1 *}$, Efka Zabokova-Bilbilova $^{1}$, Zlatko Georgiev $^{1}$, \\ Emilija Bajraktarova Valjakova ${ }^{2}$, Ljube Ivkovski $^{3}$ \\ ${ }^{I}$ Department of Pediatric and Preventive Dentistry, Faculty of Dentistry, \\ Ss. Cyril and Methodius University, Majka Tereza 17, 1000 Skopje, Republic of Macedonia \\ ${ }^{2}$ Department of Prosthodontics, Faculty of Dentistry, Ss. Cyril and Methodius University, \\ Majka Tereza 17, 1000 Skopje, Republic of Macedonia \\ ${ }^{3}$ Histolab, Diagnostic Laboratory for Histopathology and Clinical Cytology, \\ 50 Divizija 34, 1000 Skopje, Republic of Macedonia
}

Received: May 2017; Accepted: July 2017

\begin{abstract}
Antigen-presenting cells are capable of participating in the stimulation of $\mathrm{T}$ cells by antigen presentation. Antigen-presenting cells are considered essential for the induction and expansion of the immune reaction, because their interaction with antigen is the first step in immune induction.

We have studied the distribution of class II-expressing cells in developing, healthy and carious human teeth to clarify when human pulp acquires an immunologic defense potential. Antigen-expressing cells were identified immunohistochemically with HLA-DR monoclonal antibodies (for dendritic cells) and CD68 monoclonal antibodies (for macrophages).

In the pulp of unerupted developing teeth, HLA-DR-positive cells were distributed mainly in and around the odontoblast layer. A few CD68 positive cells were located more coronary around the blood vessels. In erupted teeth, HLA-DR-positive cells were located, for the most part just beneath the odontoblast layer. CD68 positive cells were also located coronary mainly around the blood vessels. Superficial caries lesions caused an aggregation of HLA-DR-positive cells and macrophages in the dental pulp corresponding to the lesion.

Our results showed that human teeth are already equipped with an immunological defense potential prior to eruption. In the initial stage of caries infection, an immunoresponse mediated by class-II-expressing cells is initiated in human dental pulp.
\end{abstract}

Keywords: human dental pulp, developing tooth, dental caries, dendritic cells, macrophages, immunohistochemistry

\section{Introduction}

Various types of immunocompetent cells are known to be present in normal dental pulp (Cox, 1992; Jontell et al., 1987, Jontell et al., 1992, Okiji et al., 1992).

Antigen-presenting cells are considered essential for the induction and expansion of the immune reaction, because their interaction with antigen is the first step in immune induction. One of their essential characteristics is to express MHC class II antigen in the lymphoid tissue. They can absorb and process complex antigens and present them to $\mathrm{T}$ lymphocytes, a function essential to the initiation of immune responses (Ohshima et al., 1994; Steinman, 1991).

\footnotetext{
*anasotirovska@yahoo.com
} 
The hard-tissue encasement provides a unique pathway of antigenic entry, since the permeability of dentin seems to be critical in determining the quantity of incoming antigens and subsequently the magnitude of the reactions operational in the underlying pulp. There is some evidence showing that pulpal dendritic cells are actually able to respond to trans-dentinal antigen provocation, and that the kinetics of these cells are strongly influenced by changes in dentin permeability. The initial response of pulpal dendritic cells may trigger the development of most pulpal pathosis of clinical importance. Upon antigenic challenge, these cells may not only interact locally with T-lymphocytes as antigenpresenting cells but also communicate with nerves and the vasvascular systems which may modulate inflammatory reactions. Hence, pulpal dendritic cells appear to provide the pulpal connective tissue with potentials far beyond what has been previously anticipated (Ebersole, 1992; Fleming, 1985).

Changes of the distribution of class II-expressing cells have been shown in rat incisors during tooth development, as well as in molar pulp and the responses of class II-expressing cells to experimentally induced pulpitis have also been reported (Bergenholtz et al., 1991; Jontell et al., 1991; Kosaka et al., 1992; Ohshima et al., 1992).

Izumi et al. (1996) have shown that human dental pulp contains two kinds of class II MHC antigenexpressing cells: dendritic cells and macrophages (Ohshima et al., 1999). Both dendritic cells and macrophages are believed to participate in the immune defense system in the dental pulp. Class II moleculeexpressing pulpal dendritic cells are of primary importance because of their critical role in pulpal immunosurveillance. In general, dendritic cells differ from the macrophages in their having little or no phagocytotic activity, in contrast to the macrophages, which possess a high phagocytotic activity (Jontell et al., 1994; Kim et al., 1998). In intact teeth, enamel and cementum protect dentinal pulp from external stimuli transmitted through dentinal tubules. Under various conditions, however, the pulp tissue is subject to constant exposure. These differences in environment might affect the distribution of class II-expressing cells in dental pulp (Farges et al., 2013; Kamel et al., 1997).

The purpose of this study was to elucidate the distribution of class II-expressing cells in developing, healthy and carious human teeth, to clarify when human pulp acquires an immunologic defense potential and how this reacts to dental caries.

\section{Material and methods}

Four partially developed unerupted teeth were operatively extracted, four erupted developing intact premolars, and four premolars with closed apices were extracted. Ten premolars with various stages of decay were obtained from patients exhibiting no clinical symptoms. Teeth were obtained from patient who needed orthodontic therapy and were from 11 to 18 years old.

Immediately after extraction, the teeth were cut longitudinally; the pulp was extirpated and fixed in $10 \%$ buffered paraformaldehyde, embedded in paraffine and sliced into $4-5 \mu \mathrm{m}$ sections. After deparaffinisation, immunoperoxidase staining was performed, with use of monoclonal antibodies. The commercially available primary antibodies were anti-HLA-DR monoclonal antibody (CR3/43; DAKO Co. Ltd, Denmark) and rabbit anti-CD 68 polyclonal antibody (DAKO). The sections were further incubated with pre-formed $\mathrm{ABC}$ (Elite ${ }^{\circledR}$ ABC, VECTOR Laboratories, Burlingame, USA) for 30 min. at room temperature. Finally, the localization of peroxidase activity was made visible by incubation of the sections with 3'.3'- Diaminobezidin (DAB) in PBS buffer for five to seven minutes and counterstained with hematoxylin. The depth of each caries lesion was determined by the pigmentation on the sections.

\section{Results}

\section{Unerupted developing teeth}

During the stage of root formation, numerous HLADR-possitive cells and macrophages appeared in the coronal pulp. Distribution of HLA-DR-positive cells was especially dense in and around the odontoblast layer. Only a few HLA-DR-possitive cells were scattered in the dental papilla (Fig. 1).

A few CD68 positive cells were located more coronary around the blood vessels (Fig. 2).

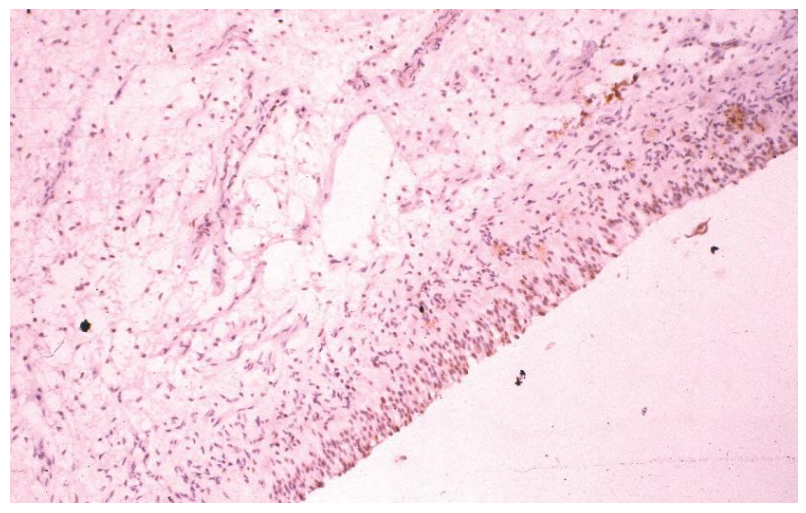

Fig. 1 Immunohistochemical localization of HLA-DR positive cells in unerupted developing teeth.

\section{Erupted, intact teeth}

Immunoperoxidase-labeled HLA-DR-positive cells were located, for the most part just beneath the odontoblast layer. In the connective tissue of the coronal 


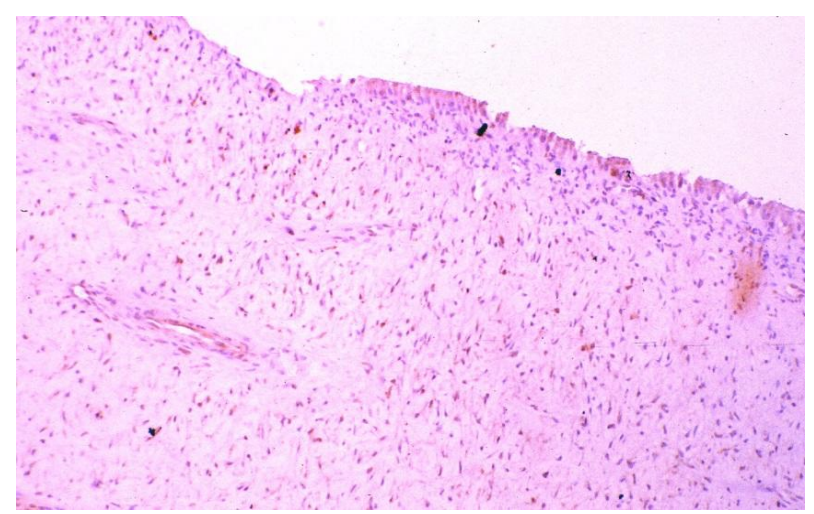

Fig. 2 Immunohistochemical localization of CD68 positive cells in unerupted developing teeth.

and radicular pulp they were distributed mainly around the blood vessels (Fig.3).

CD68 positive cells were also located coronary mainly around the blood vessels (Fig. 4).

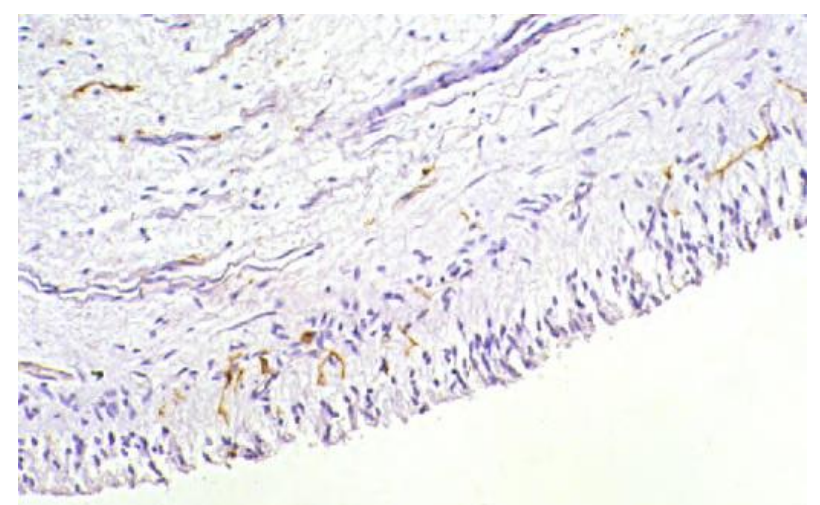

Fig. 3 Immunohistochemical localization of HLADR positive cells in erupted, intact teeth.

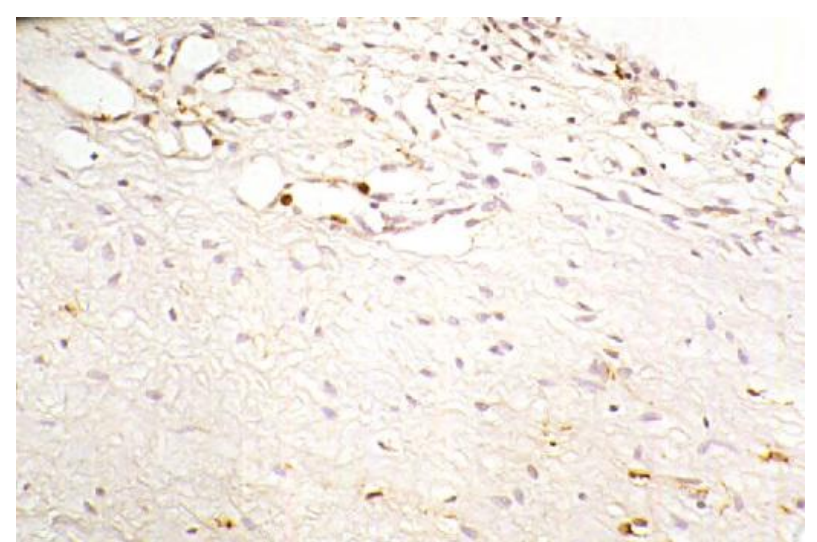

Fig. 4 Immunohistochemical localization of CD68 positive cells in erupted, intact teeth.

\section{Carious teeth}

In teeth where caries lesions extended from the enamel into the dentin, an aggregation of HLA-DRpossitive cells were observed in the subodontoblastic region. No distributive changes were noted in other areas (Fig.5). Also, the number of the macrophages was increased in the area corresponding to the caries lesion (Fig.6).

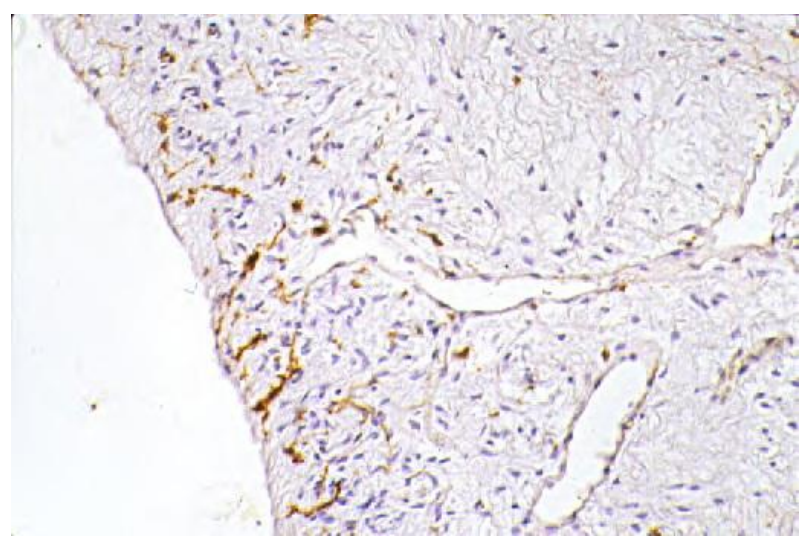

Fig. 5 Immunohistochemical localization of HLADR positive cells in the pulp affected by initial caries.

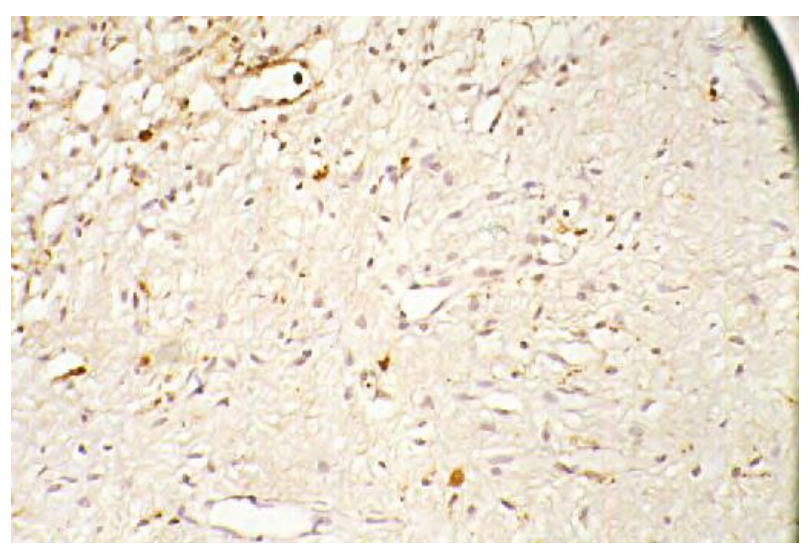

Fig. 6 Immunohistochemical localization of CD68 positive cells in the pulp affected by initial caries.

As the caries lesion advanced, the aggregated cells expanded along the odontoblast layer, and they advanced toward the center of the pulp (Fig.7 and Fig.8).

\section{Discussion}

The existence of two types of class II antigenexpressing cells-dendritic cells, which are characterized 


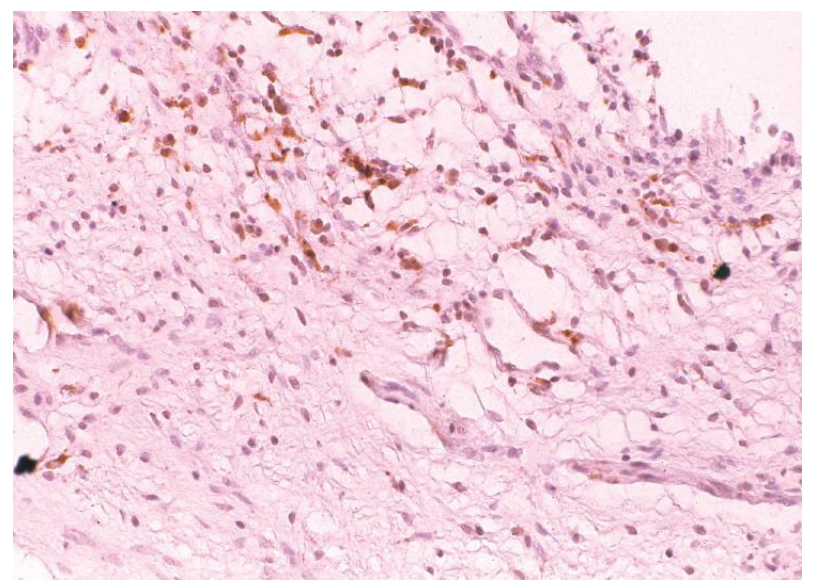

Fig. 7 Immunohistochemical localization of HLADR positive cells in the pulp affected by moderate caries.

by poor phagocytic activity, and macrophages has been reported in the dental pulp of both rat and human teeth (Oshima et al., 1995). Dendritic cells are localized to the periphery of the pulp, while macrophages tend to be more centrally located (Jontell et al., 1987; Jontell et al., 1998).

The HLA-DR-positive cells observed throughout the odontoblast layer are dendritic cells, and their location is ideal for capturing antigens invading the dental tubules (Bachereau et al., 2001; Reschigno et al., 2001). Previous studies of Jontell et al. (1991), Kosakaet et al. (1992) and Yoshiba et al. (1996) on rat dental pulp have shown that the majority of class II- expressing cells occur only after eruption, suggesting that there is a post-eruptive increase due to the invasion of bacterial antigens. Contrary, to the data obtained in rats, numerous HLA-DR-positive cells were found in the pulps of unerupted human teeth concentrated within the odontoblast layer, and macrophages more centrally located around the blood vessels. Thus, the results of the present study indicate that human teeth are already equipped with an immmunological defence potential before they erupt.

Antigen-presenting cells react with antigens that have reached the pulp tissue through the dentine tubules (Lehner, 1992). Therefore, these cells in the early carious pulp may migrate into the lymph node to present antigen to $\mathrm{T}$ cells. Initial antigen presentation followed by expansion of both the cell-mediated and the humoral immune reaction may occur in the dental pulp. Potential antigen-presenting cells in the pulp actually respond to the carious attack at the very early stage of dentinal caries. Most likely these cells are functioning as sentinels of the pulpal immunological defense system to recognize externally derived carious antigens, which may activatate the pulpal immune defense reactions (Sakurai et al., 1999).

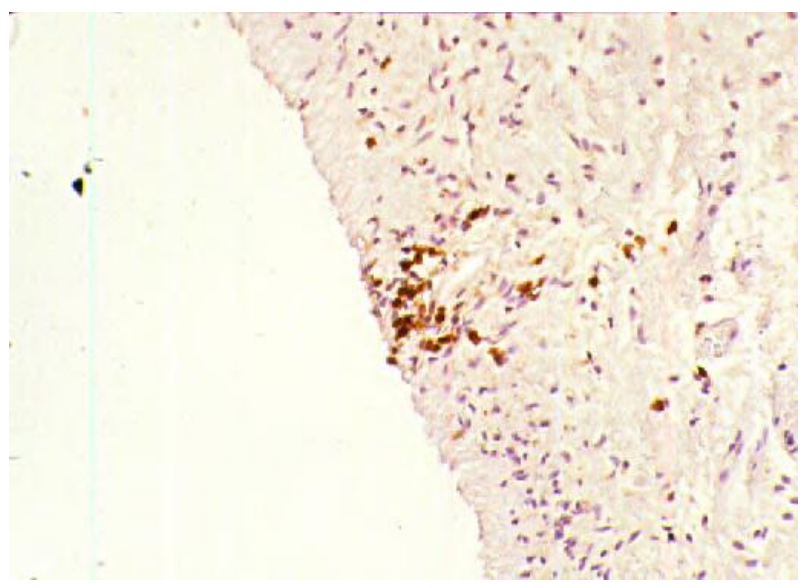

Fig. 8 Immunohistochemical localization of CD68 positive cells in the pulp affected by moderate caries.

Present study is also demonstrating distributive changes in class II-expressing cells in the pulps of carious teeth. Changes were evident in teeth with early caries and the aggregation of HLA-DR-positive cells and macrophages were observed in the restricted area corresponding to caries lesion, which is suggesting that antigenic materials have already spread into the pulp tissue through dentinal tubules. Similar lymphocyte infiltration was reported during enamel caries (Izumi et al., 1995; Nahn et al., 2007; Sotirovska Ivkovska et al., 2000). The relationship between these data on carious teeth is suggested by the results of in vitro experiments which show that dendritic cells in dental pulp have the capacity to co-stimulate T-lymphocytes, a relationship of importance during the early stages of pulpal immunoresponse (Jontell et al., 1994).

More advanced caries induced more expanded aggregations of HLA-DR-positive cells and macrophages along the odontoblast layer and subodontoblastic area of the pulp. This subodontoblastic zone is composed of the rich network of nerve fibers, capillaries and a collagen matrix (Goldberg et al., 2008). The exact role of this zone remains unknown, but the present findings suggest its importance for accommodating immunoresponsive cells. HLA-DR-positive cells were observed along the dentin pulp border corresponding to the caries lesion.

The mode of immunological reaction of the dental pulp seems to be strongly influenced by hard tissue encasement. Class-II-expressing cells are able to respond to trans dentinal antigen provocation and the kinetics of these cells are strongly influenced by changes in dentin permeability (Jontell et al, 1998; Taubman, 1992). Upon antigenic challenge, these cells may interact locally with T-lymphocytes and induce an immunological response to mount defense and repair of the dentin pulp complex. 


\section{Conclusions}

Our present findings indicate that human teeth are already equipped with an immunological defense potential prior to eruption, even before they are submitted to antigenic challenges in the mouth. In the initial stage of caries infection, an immunoresponse mediated by class-IIexpressing cells is initiated in human dental pulp.

\section{References}

Banchereau, J., Steinman, R.M., 1998. Dendritic cells and the control of immunity. Nature 392, 245-252. Available at: https://doi.org/10.1038/32588.

Bergenholtz, G., Nagaoka, S., Jontell, M., 1991. Class II antigen expressing cells in experimentally induced pulpitis. Int. Endod. J. 24, 8-14. Available at: https://doi.org/10.1111/j.1365-2591.1991.tb00864.x.

Cox, D.S., 1992. Inflammation, hypersensitivity and regulatory mediators. In: Contemporary oral microbiology and immunology. Slots, J., Taubman, M.A., (Eds.), Mosby, Baltimore, pp 135-143.

Ebersole, J.L., 1992. Cells and tissues of the immune system. In: Contemporary oral microbiology and immunology. Slots J, Taubman, M.A., (Eds.), Mosby, Baltimore, pp 78-116.

Farges, J.C., Alliot-Licht, B., Baudouin, C., Msika, P., Bleicher, F., Carrouel, F., 2013. Odontoblast control of dental pulp inflammation triggered by cariogenic bacteria. Front. Physiol. 4, 326. Available at: https://doi.org/10.3389/fphys.2013.00326.

Fleming, S., 1985. Immunophysiology: the Immune Response. In: Muir's Textbook of Pathology. Anderson, J.R., (Eds.), 12th ed, 6.1-6.40. Arnold, Baltimore.

Goldberg, M., Farges, J.C., Lacerda-Pinheiro, S., Six, N., Jegat, N., Decup, F., Septier, D., Carrouel, F., Durand, S., Chaussain-Miller, C., Denbesten, P., Veis, A., Poliard, A., 2008. Inflammatory and immunological aspects of dental pulp repair. Pharmacol. Res. 58(2), 137-147. Available at:

https://doi.org/10.1016/j.phrs.2008.05.013.

Izumi, T., Kobayashi, I., Okamura, K., Matsuo, K., Kiyoshima, T., Ishibashi, Y., Inoue, H., Sakai, H., 1996. An immunohistochemical study of HLA-DR and $\alpha 1$ antichimotrypsin-positive cells in the pulp of human noncarious and carious teeth. Arch. Oral. Biol. 41(7), 627-630. Available at: https://doi.org/10.1016/S00039969(96)00075-1.

Izumi, T., Kobayashi, I., Okamura, K., Sakai, H., 1995. Immunohistochemical study on the immunocompetent cells of the pulp in human non-carious and carious teeth. Arch. Oral. Biol. 40(7), 609-614. Available at: https://doi.org/10.1016/0003-9969(95)00024-J.

Jontell, M., Bergenholtz, G., 1992. Accessory cells in the immune defense of the dental pulp. Proc. Finn. Dent. Soc. 88, 344-355.

Jontell, M., Bergenholtz, G., Scheynius, A., Ambrose, W., 1998. Dendritic cells and Macrophages expressing class II antigens in the normal rat incisor pulp. J. Dent. Res. 67(10),
1263-1266. Available at: https://doi.org/10.1177/00220345880670100301.

Jontell, M., Eklog, C., Dahlgren, U.I., Bergenholtz, G., 1994. Difference in capacity between macrophages and dendritic cells from rat incisor pulp to provide accesory signals to concavalin-A-stimulated T-lymphocytes. J. Dent. Res. 73(5), 1056-1060. Available at: https://doi.org/10.1177/00220345940730050701.

Jontell, M., Gunray, M.N., Bergenholtz, G., 1987. Immunocompetent cells in the normal dental pulp. J. Dent. Res. 66, 1149-1153. Available at: https://doi.org/10.1177/00220345870660061101.

Jontell, M., Jiang, W.H., Bergenholtz, G., 1991. Ontogeny of class II antigen expressing cells in rat incisor pulp. Scand. J. Dent. Res. 99, 84-389. Available at: https://doi.org/10.1111/j.1600-0722.1991.tb01045.x.

Jontell, M., Okiji, T., Dahlgreen, U., Bergenholtz, G., 1998. Immune defence mechanisms of the dental pulp. Crit. Rev. Oral. Biol. Med. 9(2), 179-200. Available at: https://doi.org/10.1155/2015/230251.

Kamal, A.M.M., Okiji, T., Kawashima, N., Suda, N., 1997. Defence responses of dentin/pulp complex experimentally induced caries in rat molars: An immunohistochemical study on kinetics of pulpal Ia antigen-expressing cells and macrophages. J. Endod. 23(2), 115-120. Available at: https://doi.org/10.1016/s0099-2399(97)80257-9.

Kim, S., Trowbridge, H.O., 1998. Pulpal reaction to caries and dental procedures. In: Pathways of the pulp, 7th ed. Mosby, Baltimore.

Kosaka, T., Okiji, T., Kawashima, N., Kobayashi, C., Suda, H., 1992. Changes in the distribution of various immunocompetent cells in rat molar pulp during tooth development. Jpn. J. Conserv. Dent. 35, 1474-1480.

Lehner, T., 1992. Immunology of oral diseases, third ed. Blackwell Scientific Publications, Oxford.

Nahn, C.L., Liewehr, F.R., 2007. Innate immune responses of the dental pulp to caries. J. Endod. 33(6), 643-651. Available at: https://doi.org/10.1016/j.joen.2007.01.001.

Ohshima, H., Kawahara, I., Maeda, T., Takano, Y., 1994. The relationship between odontoblasts and immunocompetent cells during dentinogenesis in rat incisors: an immunohistochemical study using OX6-monoclonal antibody. Arch. Histol. Cytol. 57, 435-447. Available at: https://doi.org/10.1679/aohc.57.435.

Ohshima, H., Maeda, T., Takano, Y., 1999. The distribution and ultrastructure of class II MHC-positive cells in human dental pulp. Cell. Tissue. Res. 295, 151-158. Available at: https://doi.org/10.1007/s004410051221.

Ohshima, H., Sato, O., Kawahara, I., Maeda, T., Takano, Y., 1995. Responses of immunocompetent cells to cavity preparation in rat molars: An immunohistochemical study using OX6-monoclonal antibody. Connect. Tissue. Res. 32, 303-311. Available at: https://doi.org/10.3109/03008209509013738.

Okiji, T., Kawashima, N., Kosaka, T., Matsumoto, A., Kobayashi, C., Suda, H., 1992. An immunohistochemical study of the distribution of imunocompetent cells, especially macrophages and Ia antigen-expressing cells of heterogenous populations, in normal rat molar pulp. J. Dent. Res. 71(5), 1196-1202. Available at: https://doi.org/10.1177/00220345920710051201.

Rescigno, M., Urbano, M., Valzasina, B., Francolini, M., Rotta, 
G., Bonasio, R., Granucci, F., Kraehenbuhl, J.P., Ricciardi-Castagnoli, P., 2001. Dendritic cells express tight junction proteins and penetrate gut epithelial monolayers to sample bacteria. Nat. Immunol. 2(4), 361367. Available at: https://doi.org/10.1038/86373.

Sakurai, K., Okiji, T., Suda, H., 1999. Co-increase of nerve fibers and HLA-DR-and/or factor-XIII a-expressing dendritic cells in dentinal caries-affected regions of the human dental pulp: An immunohistochemical study. J. Dent. Res. 78(10), 1596-1608. Available at: https://doi.org/10.1177/00220345990780100401.

Sotirovska Ivkovska, A., Ivkovski, Lj., Bajraktarova, B., Georgiev, Z., Zabokova-Bilbilova, E., 2000. An immunohistochemical study of antigen-presenting cells in the human dental pulp. Int. Dent. J. (Supplement) 6, 353.
Available at: https://doi.org/10.4149/BLL_2018_047.

Steinman, P.M., 1991. The dendritic cell system and its role in immunogenicity. Ann. Rev. Immunol. 9, 271-296. Available at: https://doi.org/10.1146/annurev.iy.09.040191.001415.

Taubman, M.A., 1992. Immunological aspects of dental caries. In: Contemporary oral microbiology and immunology. Slots, J., Taubman, M.A. (Eds.), Mosby, Baltimore, pp 533-541.

Yoshiba, N., Yoshiba, K., Nakamura, H., Iwaku, M., Ozawa, H., 1996. Immunohistochemical localization of HLA-DR-positive cells in unerupted and erupted normal and carious human teeth. J. Dent. Res. 75, 1585-1589. Available at: https://doi.org/10.1177/00220345960750081001

\title{
Вроден имунолошки одговор на денталната пулпа кај здрави и кариозни променети хумани заби
}

\author{
Ана Сотировска Ивковска ${ }^{1 *}$, Ефка Жабокова-Билбилова ${ }^{1}$, Златко Георгиев ${ }^{1}$, \\ Емилија Бајрактарова Ваљакова ${ }^{2}$, Љубе Ивковски ${ }^{3}$ \\ ${ }^{I}$ Клиника за детска и превентивна стоматологија, Стоматолошки факултет, \\ Универзитет „Св. Кирил и Методиј”, Мајка Тереза 17, 1000 Скопје, \\ Република Македонија \\ ${ }^{2}$ Клиника за протетика, Стоматолошки факултет, \\ Универзитет „Св. Кирил и Методиј”, Мајка Тереза 17, 1000 Скопје, \\ Република Македонија \\ ${ }^{3}$ Хистолаб, Дијагностичка лабораторија за хистопатологија и клиничка циитологија, \\ 50 Дивизија 34, 1000 Скопје, Република Македонија
}

Клучни зборови: хумана забна пулпа, заби во развој, забен кариес, дендритични клетки, макрофаги, имунохистохемија

Антиген-презентирачките клетки се способни да учествуваат во стимулацијата на Т-клетките преку антигенска презентација. Антиген-презентирачките клетки се сметаат за суштински за започнување и понатамошна експанзија на имунолошката реакција, бидејќи нивната интеракција со антигенот е првиот чекор во имунолошката реакција.

Ние ја проучувавме дистрибуцијата на клетки кои презентираат класа II антигени кај заби во развој, здрави и кариозно променети хумани заби за да одредиме кога човечката пулпа се здобива со имунолошки одбранбен потенцијал. Антиген-презентирачките клетки беа идентификувани имунохистохемиски со моноклонални антитела на HLA-DR (за дендритични клетки) и CD68 моноклонални антитела (за макрофаги).

Во пулпата на заби кои не беа еруптирани, HLA-DR-позитивните клетки беа дистрибуирани главно во и околу слојот на одонтобласти. Неколку CD68 позитивни клетки се наоѓаа повеќе коронарно околу крвните садови. Кај еруптираните заби, HLA-DR-позитивните клетки беа лоцирани, во најголем дел само под слојот на одонтобласти. CD68 позитивните клетки исто така се наоѓаa коронарно главно околу крвните садови. Површинските кариозни лезии предизвикаа агрегација на HLA-DR-позитивни клетки и макрофаги во забната пулпа што соодветствува на длабочината на лезијата.

Нашите резултати покажаа дека хуманите заби се веќе опремени со имунолошки одбранбен потенцијал пред ерупцијата. Во почетната фаза на кариозната лезија, имунолошкиот одговор посредуван од клетки кои презентираат класа II антигени е инициран во хуманата дентална пулпа. 